\title{
Review
}

Journal of Innate

Immunity
J Innate Immun 2010;2:307-315

DOI: $\underline{10.1159 / 000314270}$
Received: January 20, 2010

Accepted after revision: February 21, 2010

Published online: April 30, 2010

\section{Endogenous Inflammatory Molecules Engage Toll-Like Receptors in Cardiovascular Disease}

\author{
Mihaela G. Ionita ${ }^{a}$ Fatih Arslan $^{a}$ Dominique P.V. de Kleijn ${ }^{a}$ b \\ Gerard Pasterkamp ${ }^{\text {a }}$ \\ ${ }^{a}$ Experimental Cardiology Laboratory, Cardiology, University Medical Center Utrecht, and \\ bInteruniversity Cardiology Institute of the Netherlands (ICIN), Utrecht, The Netherlands
}

\section{Key Words}

Inflammation • Toll-like receptor • Endogenous ligand •

Atherosclerosis $\cdot$ Cardiac ischemia $\cdot$ Myeloid-related

protein-8/14

\begin{abstract}
Innate immunity is important in the pathogenesis and progression of cardiovascular disease. Innate immune cells express various pattern-recognition receptors, among which also Toll-like receptors (TLRs). TLRs occur in atherosclerotic lesions where they are triggered by both exogenous (bacterial and viral pathogens) and endogenous (tissue damageassociated) molecules. Several endogenous TLR activators are described in relation to atherosclerotic disease or ischemia-induced cardiac injury. Experimental animal models have proved the role of TLR endogenous activators in disease initiation and further development. Nowadays, researchers aim to unravel the exact mechanisms involved in the endogenous ligand-dependent TLR signaling and to discover new potential activators, released during pathological conditions such as atherosclerosis and related ischemic manifestations. This review provides an overview of the currently known endogenous molecules which trigger innate immunity via TLRs in cardiovascular disease.
\end{abstract}

Copyright $\odot 2010$ S. Karger AG, Basel

\section{KARGER}

Fax +4161306 1234

E-Mail karger@karger.ch

www.karger.com (c) 2010 S. Karger AG, Basel

1662-811X/10/0024-0307\$26.00/0

Accessible online at:

www.karger.com/jin

\section{Introduction}

For decades, morbidity and mortality of the aging population due to cardiovascular disease (CVD) has been a burden for the health system and regrettably, we witness no revolution at the beginning of the 21st century. Along with a boost of hypertension, type II diabetes and obesity in the young generation, the incidence of CVD is rapidly increasing, with heart disease being the major cause of death in the modern world. The pathogenesis of CVDs is heterogeneous; infection, inflammation $[1,2]$ and even autoimmunity [3] are implicated. For most clinical presentations of CVD (such as stroke and acute coronary syndromes), atherosclerosis is the underlining pathological cause. Long considered a passive lipid deposition on the vessel wall, atherosclerosis is nowadays reckoned as a complex inflammatory process that involves both arms of immunity: innate and adaptive [4]. Immunity mediates the initiation, progression and eventual thrombotic complications of atherosclerosis [4]. The innate immune response rises quickly after a danger signal and combats foreign pathogens but also self-structures released under cell stress. It demands no prior 'education' of the immune cells and can recognize hundreds of different structures, therefore being labeled as 'fast and blunt'. Fundamental 
cells of the innate immune system, namely monocytes and macrophages, are present within atherosclerotic lesions and express various pattern-recognition receptors, among which, Toll-like receptors (TLRs). TLRs occur in atherosclerotic lesions [5] where they are triggered by both exogenous (bacterial and viral pathogens) and endogenous (tissue damage-associated) molecules [6]. Several endogenous ligands for TLRs are expressed during inflammation in atherosclerotic plaques or ischemic heart where they might play a role in disease pathogenesis and progression. With the use of experimental animal models, researchers have gained insight into the mechanisms behind endogenous ligand-induced TLR activation.

This review provides an overview of the endogenous molecules, released under cell stress during inflammation, which can trigger innate immunity via TLRs in CVDs.

\section{The Role of TLRs in CVD}

TLRs, especially TLR-2 and TLR-4, are extensively studied in CVD and implicit in atherosclerosis. TLRs are important components of innate immunity that bridge inflammation, infection and atherosclerosis [7]. Atherosclerosis is a chronic inflammatory process affecting the vasculature at predetermined sites. Lipid accumulation within the vessel intima leads, in time, to an accelerated inflammatory response that encompasses both innate and adaptive immune systems. Previous epidemiological studies have proved that exogenous bacterial ligands can induce an inflammatory response in the arterial wall and initiate atherosclerosis [8], and therefore, a link between atherosclerosis and TLRs has been established. Experimental data have shown that lipopolysaccharide (LPS) and peptidoglycan (PGN), both potent TLR activators, can accelerate plaque formation in atherosclerotic mice [6]. These results point to a potential role of TLR-2 and TLR-4 in the pathogenesis of atherosclerotic disease. Indeed, TLR-2 knockout mice crossed with low-density lipoprotein (LDL) receptor show a reduction in the degree of atherosclerosis [9]. TLR-4 knockout mice crossed with the apolipoprotein $\mathrm{E}$ (ApoE) knockout mice have reduced atherosclerosis compared to apoE knockout controls [10]. TLR-4-deficient mice also reveal reduced outward arterial remodeling [11]. apoE-deficient mice lacking TLR-4 and myeloid differentiation factor 8 (MyD88), a signal protein downstream TLR pathway, have reduced aortic atherosclerosis that is associated with reductions in cir- culating levels of pro-inflammatory cytokine interleukin (IL)-12 or monocyte chemoattractant protein 1, plaque lipid content, numbers of macrophages and cyclooxygenase-2 immunoreactivity in their plaques [12]. Another group has reported reduced atherosclerosis through a decrease in chemokine levels and in macrophages infiltrating into plaques, in apoE/MyD88 null mice [13].

The relation between TLR- 4 and atherosclerosis is strengthened by genetic analyses of polymorphisms in genes encoding TLR-4. However, large clinical studies have brought contradictory findings: TLR-4 polymorphism is related to a reduction [14] or no effect [15] on atherosclerosis and in intima-media thickness, to an increased risk of ischemic stroke [16] and MI [17], or to a decreased risk of acute coronary syndromes [18]. Others have reported no association between TLR-4 polymorphisms and the risk of acute ischemic events $[19,20]$.

Frantz et al. [21] were among the first to study the role of TLRs in the inflammatory response due to cardiac ischemia and they have triggered extensive research in the field of TLRs and cardiac ischemia-related pathological conditions. Their observation that TLR- 4 is upregulated in heart failure [21] has been confirmed in TLR-4 knockout mice which are relatively protected against adverse ventricular remodeling after infarction [22]. The association of TLR-4 signaling with myocardial ischemia/ reperfusion injury is documented in various studies [2326], and, moreover, the pharmacological inhibition of TLR-4 signaling reduces infarct size [27]. In humans, circulating TLR-4-positive cells and TLR-4 signaling are increased in patients with unstable angina and myocardial infarction [28].

Similar experimental proofs are present for TLR-2, as a critical modulator of post-infarct injury and repair. TLR-2 knockout mice have higher survival rates and less expansive remodeling after infarction [29]. In a murine myocardial ischemia/reperfusion injury model, we and others have shown that lethal reperfusion injury is mediated by circulating TLR-2. Administration of a monoclonal anti-TLR-2 antibody at a clinically applicable time point reduces infarct size with approximately $50 \%$ and improves cardiac function $[30,31]$. These data, together with the fact that the postinfarct period and TLR-2 and -4 signaling share similar immunological characteristics [32], suggest that TLR-2 and -4 are promising therapeutic targets in cardiac ischemia. It is expected that in the near future these promising compounds will enter clinical trials for their efficacy and feasibility. 
Fig. 1. Schematic representation of potential toll-like receptor ligands (exogenous and endogenous).

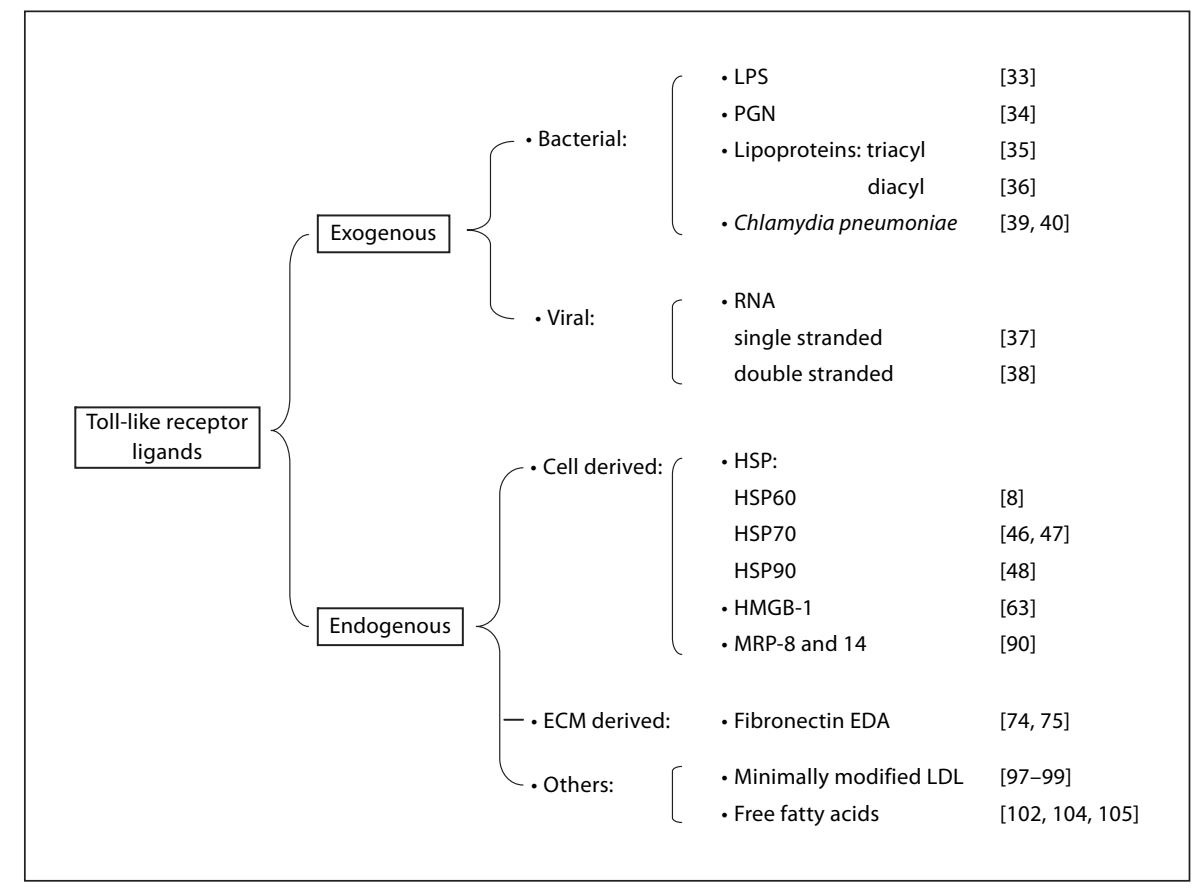

\section{Potential Endogenous Activators of TLRs: Expression and Role in CVD}

TLRs were initially described as recognizing proteins for bacterial and viral antigens. Bacterial LPS [33], PGN [34], different bacterial lipoproteins (triacyl [35], diacyl [36]) and single [37] or double-stranded viral RNA [38] signal via TLRs. Chlamydia pneumoniae, an infectious agent which happens to be a potent TLR activator, is found in different atherosclerotic lesions [39]. In animal models C. pneumoniae can stimulate atherogenesis [40] and therefore is considered a therapeutic target for atherosclerosis [41]. PGN, a TLR-2 ligand, is present in the bacterial flora at all mucosal sites from where it can travel along the bloodstream via monocytes. PGN is an exogenous microbial-derived TLR ligand and activator that is widely present in the gut of each individual. PG-loaded monocytes adhere to the activated endothelium at sites of inflammation and are found in atherosclerotic plaques with features of unstable/rupture-prone lesions [42].

Along with the classical bacterial and viral antigen recognition, TLRs are able to respond to endogenous molecules released during tissue injury $[43,44]$. Below we summarize (see also fig. 1) and discuss the role of potential TLR endogenous activators in the progression of CVDs.

Heat-shock proteins (HSPs) are present in most cells, serving as molecular chaperones, and play a role in cell protection from damage in response to stress stimuli [45]. TLR-2 and TLR-4 are able to recognize and respond to the soluble forms of HSP60 [8], HSP70 [46, 47] and the endoplasmic reticulum HSP90 (GP96) [48]. Several groups have reported that in human mononuclear cells, human soluble HSP60 binds to TLR-4/CD14, leading to p38 mitogen-activated protein kinase activation [49], whereas in smooth muscle and epithelial cells chlamydial and human soluble HSP60 stimulates extracellular signal-regulated kinase $42 / 44$ activation [50]. In macrophages and endothelial cells, the binding of soluble HSP60 to the TLR-4/CD14 complex leads to the activation of MyD88-NF- $\kappa B$ pathways; the same TLR-4-mediated signal pathway is described for soluble HSP70 [51].

HSPs have been found to be highly expressed in cardiovascular tissues and to induce inflammatory responses. These proteins are expressed during the development of atherosclerosis and elicit an immune response as autoantigens [52]. HSP60 is observed in the cell mitochondria (endothelial, smooth muscle cells and mononuclear cells of the carotid and aortic plaque specimens) [53] and is transported to the cell membrane in response to stress stimuli. Auto-antibodies against HSP60 (demonstrated in patients with heart attacks and strokes) bind to cell membrane-exposed HSP60 and therefore induce damage of the cell [54]. 
HSPs are secreted under stress stimuli and the soluble forms have pro-inflammatory activities [55]; Chen et al. [56] have demonstrated that autologous HSP60 serves as a danger signal to the innate immune system, which results in pro-inflammatory responses, including the production of tumor necrosis factor (TNF)- $\alpha$, IL-12, and IL15. The soluble HSP60 is found in high concentrations in the serum of subjects with prevalent/incident carotid atherosclerosis [55]. The intensity of HSP60 expression in human plaque specimens positively correlates with the atherosclerotic severity $[53,57]$.

Furthermore, the expressions of HSP60 and the stressinducible form of HSP70 correlate with the development of atherosclerotic lesions in the aortic tree of apoE-deficient mice [58]. Both HSPs are present on the aortic root and endothelium at lesion-prone sites of apoE knockout mice, before infiltration of mononuclear cells. The same study has shown a temporary expression of HSP60 and HSP70 on all major cell types in lesion-predisposed areas during atherogenesis [53].

Taken together, these results demonstrate that HSP60 and HSP70 are involved in both initiation as well as progression of atherosclerosis.

High-mobility group box-1 (HMGB-1) is described as a nonhistone, chromatin-associated nuclear protein [59]. HMGB-1 appears to have two distinct functions in cellular systems. First, it is an intracellular regulator of transcription, and second, HMGB-1 can occupy an extracellular role in which it promotes tumor metastasis and inflammation [60, 61]. Extracellular HMGB-1 participates in inflammatory processes and stimulates the secretion of TNF- $\alpha$ and different pro-inflammatory cytokines [60, 62]. HMGB-1 binds to TLR-2 and TLR-4 [63] and induces activation of endothelial cells and macrophages/monocytes with subsequent release of pro-inflammatory cytokines, chemokines and adhesion molecules. In human atherosclerotic plaques, HMGB-1 is highest in fibrofatty lesions where it is expressed and secreted by macrophages [64]. Along with an increase in HMGB-1 levels, also a concomitant decrease in HMGB-1 inhibitory proteins such as the anticoagulant protein thrombomodulin, which binds and sequesters HMGB-1 [65], is documented. In addition, the receptors for HMGB-1, namely TLR2, TLR-4 and receptor of advanced end glycation products (RAGE), are upregulated in atherosclerotic lesions $[66,67]$. Thus, HMGB-1 might be an important molecule linking innate immunity and inflammation in the pathogenesis of atherosclerosis.

HMGB-1 plays a pathogenic role in ischemic injury, because its circulating levels are increased shortly after ischemia/reperfusion, and its inhibition is protective against liver ischemia/reperfusion injury [68]. Moreover, the expression levels of TLR-2, TLR- 4 and RAGE are increased after cardiac injury [69], which might facilitate HMGB-1 to mediate an inflammatory response. In a murine myocardial ischemia/reperfusion injury model, HMGB-1 administration increases infarct size, while its inhibition significantly reduces infarct size via RAGE [70]. Several other HMGB-1-inhibiting agents (such as ethyl pyruvate, green tea and adrenomedullin) preserve cardiac function after myocardial ischemia [71, 72], consistent with a pathogenic role of HMGB-1 in CVDs.

Extradomain A of fibronectin (EDA), generated by regulated fibronectin RNA splicing [73], is absent from healthy plasma and extracellular matrix and yielded only during pathological tissue alterations. EDA is expressed after tissue injury due to inflammation and stimulates production of various cytokines [74] via TLR- 4 through NF- $\mathrm{B}$ pathway [75]. In atherosclerotic plaques, fibronectin abundantly contains EDA, whereas in the adjacent unaffected vessel wall, fibronectin lacks EDA. In a model of atherogenetic-predisposed mouse (apoE knockout), systemic as well as local (plaque) EDA levels are elevated, while mice lacking both apoE and EDA have decreased atherosclerosis (as much as 67\%) [76]. The observed effect is justified by EDA involvement in plasma lipoprotein metabolism and in macrophage foam cell formation. These observations imply a pro-atherogenic role for EDA in the pathogenesis of atherosclerosis. The findings in mice are strengthened by those in humans: our group has previously reported, in human carotid atherosclerotic plaques, high levels of fibronectin containing EDA in fibrous (more stable) and low levels in highly inflamed (unstable) lesions [77]. Additionally, patients with carotid atherosclerotic stenosis $(>75 \%)$ and no clinical-associated complains reveal high EDA plaque levels contrary to patients with clinical manifestations of carotid stenosis which have low EDA plaque levels. Although the exact role of EDA in the pathogenesis of atherosclerosis remains to be elucidated, there is no doubt that EDA is a molecule linking innate immunity and inflammation in atherosclerosis.

Myeloid-related protein (MRP)-8 and -14, also known as S100A8 and S100A9, are two calcium-binding proteins mainly expressed in cells of myeloid origin, particularly in monocytes and neutrophils [78]. Both proteins are secreted by activated monocytes and neutrophils and have pro-inflammatory effects $[79,80]$. Upon cell activation, the two proteins form a complex, MRP-8/14, that translocates to the cytoskeleton and plasma membrane where 
it is secreted [81]. Intracellularly, MRP-8 and MRP-14 essentially regulate phagocyte (monocytes and neutrophils) migration by integrating the calcium and mitogenactivated protein kinase transduction pathways, thereby controlling reorganization of the phagocyte microtubular system [82]. The secreted MRP-8/14 complex exerts antimicrobial activity [83], stimulates IL- 8 production by airway epithelial cells [84] and transports arachidonic acid to endothelial cell targets affecting pathological responses in inflammation and atherosclerosis [85]. MRP8, MRP-14 and MRP-8/14 are expressed in both mouse [86] and human atherosclerotic plaques [87]. MRP-14 and MRP-8 are expressed by subsets of macrophages during inflammation in different tissues [88] as well as in atherosclerotic lesions $[87,89]$.

Taking advantage of mice lacking functional MRP8/14 complexes, Vogl et al. [90] have identified the endogenous MRP-8 and MRP-14 as activators of TLR-4. Their study shows that even though leukocytes of the MRP-14 knockout mice have a normal TLR-4 and CD14 (TLR-4 co-receptor for LPS) cell-surface expression, they have an impaired response toward LPS stimulation with less TNF- $\alpha$ production and secretion when compared to the wild-type leukocyte; addition of extracellular MRP-8/14 compensates for the reduced response in TNF- $\alpha$ of MRP14 knockout leukocytes. Further analysis has shown that MRP-8 alone stimulates TNF- $\alpha$ RNA and protein secretion and has an additive effect on LPS-induced TNF- $\alpha$ secretion. Moreover, the same study has shown that leukocytes from mice with nonfunctional TLR-4 show no response to MRP-8. Direct binding of MRP-8 to TLR-4/ MD2 complex is confirmed by surface plasmon resonance studies [90]. These findings prove that MRP-8/14 acts as an endogenous TLR-4 activator and is involved in amplification of LPS effects on leukocytes.

Libby et al. [86] have recently shown that MRP-8/14 is critical for the biological response to vascular injury. Using mice lacking functional MRP-8/14 complexes, the authors demonstrate reduced atherosclerotic lesion area and macrophage accumulation within the lesions in MRP-14 knockout mice, supporting a role for MRP in plaque formation and development.

In human carotid endarterectomy specimens, we have previously described an association between high MRP8, MRP-14 and MRP-8/14 levels and the features of rupture-prone lesions [87], suggesting a role for MRP proteins in plaque destabilization and disruption. Additionally, we identified MRP proteins expression in a subset of nonfoam plaque macrophages, and in vitro, human monocyte-derived macrophages expressing MRP pro- teins do not acquire a foamy phenotype when fed human oxidized LDL. This indicates MRP proteins as potential regulators of macrophage phagocyte capabilities, although additional proof is required.

Systemic MRP-8/14 complex relates to cardiac ischemic events: plasma MRP-8/14 levels are elevated in patients with acute coronary syndromes compared to patients with stable coronary artery disease or with normal coronary arteries [91]. Moreover, levels of systemic MRP$8 / 14$ are elevated prior to markers of myocardial necrosis (myoglobin, creatine kinase - MB and troponin) and associated with increased risk of recurrent cardiovascular events compared to patients with lower MRP-8/14 levels [92]. Plasma MRP-8/14 concentrations are higher in patients with ST-segment elevation myocardial infarction compared to patients with stable coronary artery disease [93], and the risk of the first cardiovascular event increases with each quartile of plasma MRP-8/14.

Acknowledging all these findings, we conclude that MRP proteins are endogenous activators of TLR- 4 occurring during atherosclerosis or acute coronary syndromes, therefore exacerbating the inflammatory response associated to those diseases.

Minimally modified LDL (mmLDL) is a pro-inflammatory and pro-atherogenic lipoprotein that, in contrast to oxidized LDL, is not recognized by macrophage scavenger receptors [94]. mmLDL possesses pro-atherogenic properties; for example, it induces monocyte adhesion to endothelial cells, production of colony stimulating factors, monocyte chemotactic protein-1 and tissue factor [94-96]. mmLDL also has pro-inflammatory capabilities; it is present in atherosclerotic plaques where it binds CD14 and TLR-4 [97] on macrophages, and induces TLR-4-dependent cytokine expression [98]. In addition, mmLDL promotes TLR-4/MD-2-dependent actin polymerization and spreading of macrophages [97]. Recently, Choi et al. [99] have shown that mmLDL enhances macrophage macropinocytosis, which results in lipid accumulation in macrophages and foam cell formation, by binding to a functional TLR-4 on macrophages. Additionally, the authors injected mice with mmLDL, and have proved its uptake by circulating monocytes. Their new data indicate that circulating monocytes, under hyperlipidemic conditions, can accumulate lipoproteins which might lead to their activation and enhanced migration into the vessel intima.

The active component in $\mathrm{mmLDL}$, responsible for most of the observed effects is lipoxygenase (15LO)-cholesteryl esters. Atherosclerosis-prone mice (ApoE or LDL receptor knockout) lacking 12/15 LO (the mouse homo- 
logue of human 15LO) have reduced atherosclerosis [100]; furthermore, enhanced expression and activity of 12/ $15 \mathrm{LO}$ has been reported in macrophages and endothelial cells in atherosclerotic plaques in mice [101].

All these imply that mmLDL constitutes an endogenous activator of TLR-4 and could be involved in sustained inflammation in atherosclerosis.

Free fatty acids promote insulin resistance and atherosclerosis in mice $[102,103]$ and are proposed as endogenous activators of TLR-2 and TLR- 4 in these diseases. A saturated fatty acid, namely lauric acid, can activate TLR2 in 293T cells and TLR-4 in RAW264.7 cells [104]. Similarly, an oleate/palmitate mixture of fatty acids induces TLR-4 signaling in 293T cells and causes inflammation in wild-type but not in TLR-4-deficient adipocytes [105]. Palmitate causes TLR-4-dependent IкB $\alpha$ degradation in elicited peritoneal macrophages [102]. However, recent publications suggest that fatty acids do not directly stimulate TLR- 4 or TLR-2, and that the observed effects might be due to sample contamination with TLR-4-stimulating bacterial LPSs (endotoxin), TLR-2-stimulating lipopeptide products or with an unidentified TLR endogenous ligand [106, 107]. Therefore, the mechanisms linking high-fat diets with TLR-associated pathologies such as atherosclerosis and insulin resistance remain to be discovered.

\section{Summary}

CVD is an inflammation-driven malignancy which involves innate immune responses partially due to TLR signaling. TLRs are emerging as promising therapeutic targets for atherosclerosis and cardiac ischemia due to their involvement in disease pathogenesis. TLRs are triggered by classical bacterial and viral particles (such as $C$. pneumoniae and PGN), but recent data suggest that endogenous molecules (such as HSPs, HMGB-1, EDA and MRPs) released from cells undergoing damage can also bind and stimulate these receptors. Exogenous and endogenous TLR activators have proved to be important contributors to the progression of atherosclerosis and related thrombotic complications.

TLR-related research has gained much attention and continues to be a dynamic field since TLR discovery in humans. In the near future, studies will reveal new potential endogenous ligands and provide more mechanistic insight into their biological functions.

Especially endogenous activators are appealing for both researchers and clinicians, since they are yielded only during pathological conditions and therefore might represent useful diagnostic tools and therapeutic targets. In addition, pharmacological interventions antagonizing these endogenous molecules will likely cause fewer side effects.

\section{References}

1 Ben-Haim S, Gacinovic S, Israel O: Cardiovascular infection and inflammation. Semin Nucl Med 2009;39:103-114.

-2 Libby P, Ridker PM, Hansson GK: Inflammation in atherosclerosis: from pathophysiology to practice. J Am Coll Cardiol 2009;54: 2129-2138.

3 Zhao Q: Inflammation, autoimmunity, and atherosclerosis. Discov Med 2009;8:7-12.

4 Packard RR, Lichtman AH, Libby P: Innate and adaptive immunity in atherosclerosis. Semin Immunopathol 2009;31:5-22.

5 Edfeldt K, Swedenborg J, Hansson GK, Yan Zq: Expression of Toll-like receptors in human atherosclerotic lesions: a possible pathway for plaque activation. Circulation 2002; 105:1158-1161.

6 Oude Nijhuis MM, van Keulen JK, Pasterkamp G, Quax PH, de Kleijn DP: Activation of the innate immune system in atherosclerotic disease. Curr Pharm Des 2007;13:983994.

7 Balogh S, Kiss I, Csaszar A: Toll-like receptors: link between 'danger' ligands and plaque instability. Curr Drug Targets 2009; 10:513-518. $\checkmark 8$ Vabulas RM, Ahmad-Nejad P, da Costa C, Miethke T, Kirschning CJ, Hacker H, Wagner H: Endocytosed HSP60s use toll-like receptor 2 (TLR2) and TLR4 to activate the toll/interleukin-1 receptor signaling pathway in innate immune cells. J Biol Chem 2001;276:31332-31339.

-9 Mullick AE, Tobias PS, Curtiss LK: Modulation of atherosclerosis in mice by Toll-like receptor 2. J Clin Invest 2005;115:3149-3156.

10 Michelsen KS, Wong MH, Shah PK, Zhang W, Yano J, Doherty TM, Akira S, Rajavashisth TB, Arditi M: Lack of Toll-like receptor 4 or myeloid differentiation factor 88 reduces atherosclerosis and alters plaque phenotype in mice deficient in apolipoprotein E. Proc Natl Acad Sci USA 2004;101: 10679-10684.

11 Hollestelle SC, De Vries MR, van Keulen JK, Schoneveld AH, Vink A, Strijder CF, Van Middelaar BJ, Pasterkamp G, Quax PH, de Kleijn DP: Toll-like receptor 4 is involved in outward arterial remodeling. Circulation 2004;109:393-398.
12 Michelsen KS, Wong MH, Shah PK, Zhang W, Yano J, Doherty TM, Akira S, Rajavashisth TB, Arditi M: Lack of Toll-like receptor 4 or myeloid differentiation factor 88 reduces atherosclerosis and alters plaque phenotype in mice deficient in apolipoprotein E. Proc Natl Acad Sci USA 2004;101:10679-10684.

13 Bjorkbacka H, Kunjathoor VV, Moore KJ, Koehn S, Ordija CM, Lee MA, Means T, Halmen K, Luster AD, Golenbock DT, Freeman MW: Reduced atherosclerosis in MyD88null mice links elevated serum cholesterol levels to activation of innate immunity signaling pathways. Nat Med 2004;10:416-421.

$\checkmark 14$ Kiechl S, Lorenz E, Reindl M, Wiedermann CJ, Oberhollenzer F, Bonora E, Willeit J, Schwartz DA: Toll-like receptor 4 polymorphisms and atherogenesis. N Engl J Med 2002;347:185-192.

15 Netea MG, Hijmans A, van WS, Smilde TJ, Trip MD, Kullberg BJ, de BT, Van der Meer JW, Kastelein JJ, Stalenhoef AF: Toll-like receptor-4 Asp299Gly polymorphism does not influence progression of atherosclerosis in patients with familial hypercholesterolaemia. Eur J Clin Invest 2004;34:94-99. 
16 Lin YC, Chang YM, Yu JM, Yen JH, Chang JG, Hu CJ: Toll-like receptor 4 gene C119A but not Asp299Gly polymorphism is associated with ischemic stroke among ethnic Chinese in Taiwan. Atherosclerosis 2005; 180: 305-309.

$\checkmark 17$ Edfeldt K, Bennet AM, Eriksson P, Frostegard J, Wiman B, Hamsten A, Hansson GK, de FU, Yan ZQ: Association of hypo-responsive Toll-like receptor 4 variants with risk of myocardial infarction. Eur Heart J 2004;25: 1447-1453.

18 Ameziane N, Beillat T, Verpillat P, CholletMartin S, Aumont MC, Seknadji P, Lamotte M, Lebret D, Ollivier V, de Prost D: Association of the Toll-like receptor 4 gene Asp299Gly polymorphism with acute coronary events. Arterioscler Thromb Vasc Biol 2003; 23:e61-e64.

$\checkmark 19$ Zee RY, Hegener HH, Gould J, Ridker PM: Toll-like receptor 4 Asp299Gly gene polymorphism and risk of atherothrombosis. Stroke 2005;36:154-157.

-20 Koch W, Hoppmann P, Pfeufer A, Schomig A, Kastrati A: Toll-like receptor 4 gene polymorphisms and myocardial infarction: no association in a Caucasian population. Eur Heart J 2006;27:2524-2529.

- 21 Frantz S, Kobzik L, Kim YD, Fukazawa R, Medzhitov R, Lee RT, Kelly RA: Toll4 (TLR4) expression in cardiac myocytes in normal and failing myocardium. J Clin Invest 1999; 104:271-280.

22 Timmers L, Sluijter JP, van Keulen JK, Hoefer IE, Nederhoff MG, Goumans MJ, Doevendans PA, van Echteld CJ, Joles JA, Quax PH, Piek JJ, Pasterkamp G, de Kleijn DP: Toll-like receptor 4 mediates maladaptive left ventricular remodeling and impairs cardiac function after myocardial infarction. Circ Res 2-1-2008;102:257-264.

23 Oyama J, Blais C Jr, Liu X, Pu M, Kobzik L, Kelly RA, Bourcier T: Reduced myocardial ischemia-reperfusion injury in toll-like receptor 4-deficient mice. Circulation 2004; 109:784-789.

24 Chong AJ, Shimamoto A, Hampton CR, Takayama H, Spring DJ, Rothnie CL, Yada M, Pohlman TH, Verrier ED: Toll-like receptor 4 mediates ischemia/reperfusion injury of the heart. J Thorac Cardiovasc Surg 2004; 128:170-179.

-25 Stapel H, Kim SC, Osterkamp S, Knuefermann P, Hoeft A, Meyer R, Grohe C, Baumgarten G: Toll-like receptor 4 modulates myocardial ischaemia-reperfusion injury: role of matrix metalloproteinases. Eur J Heart Fail 2006;8:665-672.

26 Hua F, Ha T, Ma J, Li Y, Kelley J, Gao X, Browder IW, Kao RL, Williams DL, Li C: Protection against myocardial ischemia/reperfusion injury in TLR4-deficient mice is mediated through a phosphoinositide 3-kinase-dependent mechanism. J Immunol 2007;178:7317-7324.
7 Shimamoto A, Chong AJ, Yada M, Shomura $\mathrm{S}$, Takayama $\mathrm{H}$, Fleisig AJ, Agnew ML, Hampton CR, Rothnie CL, Spring DJ, Pohlman TH, Shimpo H, Verrier ED: Inhibition of Toll-like receptor 4 with eritoran attenuates myocardial ischemia-reperfusion injury. Circulation 2006;114:I270-I274.

28 Methe H, Kim JO, Kofler S, Weis M, Nabauer M, Koglin J: Expansion of circulating Tolllike receptor 4-positive monocytes in patients with acute coronary syndrome. Circulation 2005;111:2654-2661.

29 Shishido T, Nozaki N, Yamaguchi S, Shibata Y, Nitobe J, Miyamoto T, Takahashi H, Arimoto T, Maeda K, Yamakawa M, Takeuchi O, Akira S, Takeishi Y, Kubota I: Toll-like receptor-2 modulates ventricular remodeling after myocardial infarction. Circulation 2003;108:2905-2910.

30 Sakata Y, Dong JW, Vallejo JG, Huang CH, Baker JS, Tracey KJ, Tacheuchi O, Akira S, Mann DL: Toll-like receptor 2 modulates left ventricular function following ischemia-reperfusion injury. Am J Physiol Heart Circ Physiol 2007;292:H503-H509.

31 Arslan F, Smeets MB, O’Neill LA, Keogh B, McGuirk P, Timmers L, Tersteeg C, Hoefer IE, Doevendans PA, Pasterkamp G, de Kleijn DP: Myocardial ischemia/reperfusion injury is mediated by leukocytic toll-like receptor-2 and reduced by systemic administration of a novel anti-toll-like receptor-2 antibody. Circulation 2010;121:80-90.

32 Arslan F, de Kleijn DP, Timmers L, Doevendans PA, Pasterkamp G: Bridging innate immunity and myocardial ischemia/reperfusion injury: the search for therapeutic targets. Curr Pharm Des 2008;14:1205-1216.

- 33 Poltorak A, He X, Smirnova I, Liu MY, Van HC, Du X, Birdwell D, Alejos E, Silva M, Galanos C, Freudenberg M, Ricciardi-Castagnoli P, Layton B, Beutler B: Defective LPS signaling in $\mathrm{C} 3 \mathrm{H} / \mathrm{HeJ}$ and $\mathrm{C} 57 \mathrm{BL} / 10 \mathrm{ScCr}$ mice: mutations in Tlr4 gene. Science 1998; 282:2085-2088.

-34 Takeuchi O, Hoshino K, Kawai T, Sanjo H, Takada H, Ogawa T, Takeda K, Akira S: Differential roles of TLR2 and TLR4 in recognition of Gram-negative and Gram-positive bacterial cell wall components. Immunity 1999;11:443-451.

- 35 Takeuchi O, Sato S, Horiuchi T, Hoshino K, Takeda K, Dong Z, Modlin RL, Akira S: Cutting edge: role of Toll-like receptor 1 in mediating immune response to microbial lipoproteins. J Immunol 2002;169:10-14.

36 Takeuchi O, Kawai T, Muhlradt PF, Morr M, Radolf JD, Zychlinsky A, Takeda K, Akira S: Discrimination of bacterial lipoproteins by Toll-like receptor 6. Int Immunol 2001;13: 933-940.

37 Lund JM, Alexopoulou L, Sato A, Karow M, Adams NC, Gale NW, Iwasaki A, Flavell RA: Recognition of single-stranded RNA viruses by Toll-like receptor 7. Proc Natl Acad Sci USA 2004;101:5598-5603.
38 Alexopoulou L, Holt AC, Medzhitov R, Flavell RA: Recognition of double-stranded RNA and activation of NF-kappaB by Tolllike receptor 3. Nature 2001;413:732-738.

- 39 Libby P: Inflammation in atherosclerosis. Nature 2002;420:868-874.

-40 Moazed TC, Campbell LA, Rosenfeld ME, Grayston JT, Kuo CC: Chlamydia pneumoniae infection accelerates the progression of atherosclerosis in apolipoprotein E-deficient mice. J Infect Dis 1999;180:238-241.

-41 Saikku P, Leinonen M, Mattila K, Ekman MR, Nieminen MS, Makela PH, Huttunen JK, Valtonen V: Serological evidence of an association of a novel Chlamydia, TWAR, with chronic coronary heart disease and acute myocardial infarction. Lancet 1988;2: 983-986.

-42 Laman JD, Schoneveld AH, Moll FL, van Meurs M, Pasterkamp G: Significance of peptidoglycan, a proinflammatory bacterial antigen in atherosclerotic arteries and its association with vulnerable plaques. Am J Cardiol 2002;90:119-123.

-43 Beg AA: Endogenous ligands of Toll-like receptors: implications for regulating inflammatory and immune responses. Trends Immunol 2002;23:509-512.

-44 Tsan MF, Gao B: Endogenous ligands of Tolllike receptors. J Leukoc Biol 2004;76:514519.

$45 \mathrm{Xu}$ Q: Role of heat shock proteins in atherosclerosis. Arterioscler Thromb Vasc Biol 2002;22:1547-1559.

-46 Vabulas RM, Ahmad-Nejad P, Ghose S, Kirschning CJ, Issels RD, Wagner H: HSP70 as endogenous stimulus of the Toll/interleukin-1 receptor signal pathway. J Biol Chem 2002;277:15107-15112.

47 Dybdahl B, Wahba A, Lien E, Flo TH, Waage A, Qureshi N, Sellevold OFM, Espevik T, Sundan A: Inflammatory response after open heart surgery: release of heat-shock protein 70 and signaling through Toll-like receptor-4. Circulation 2002;105:685-690.

48 Vabulas RM, Braedel S, Hilf N, Singh-Jasuja H, Herter S, Ahmad-Nejad P, Kirschning CJ, da Costa C, Rammensee HG, Wagner H, Schild H: The endoplasmic reticulum-resident heat shock protein Gp96 activates dendritic cells via the Toll-like receptor $2 / 4$ pathway. J Biol Chem 2002;277:20847-20853.

49 Kol A, Lichtman AH, Finberg RW, Libby P, Kurt-Jones EA: Cutting edge: heat shock protein (HSP) 60 activates the innate immune response: $\mathrm{CD} 14$ is an essential receptor for HSP60 activation of mononuclear cells. J Immunol 2000;164:13-17.

-50 Sasu S, LaVerda D, Qureshi N, Golenbock DT, Beasley D: Chlamydia pneumoniae and chlamydial heat shock protein 60 stimulate proliferation of human vascular smooth muscle cells via Toll-like receptor 4 and p44/ p42 mitogen-activated protein kinase activation. Circ Res 2001;89:244-250. 
-51 Vabulas RM, Ahmad-Nejad P, Ghose S, Kirschning CJ, Issels RD, Wagner H: HSP70 as endogenous stimulus of the Toll/interleukin-1 receptor signal pathway. J Biol Chem 2002;277:15107-15112.

52 Pockley AG: Heat shock proteins, inflammation, and cardiovascular disease. Circulation 2002;105:1012-1017.

-53 Kleindienst R, Xu Q, Willeit J, Waldenberger FR, Weimann S, Wick G: Immunology of atherosclerosis. Demonstration of heat shock protein 60 expression and T lymphocytes bearing $\alpha / \beta$ or $\gamma / \delta$ receptor in human atherosclerotic lesions. Am J Pathol 1993; 142:1927-1937.

-54 Foteinos G, Xu Q: Immune-mediated mechanisms of endothelial damage in atherosclerosis. Autoimmunity 2009;42:627-633.

-55 Xu Q, Schett G, Perschinka H, Mayr M, Egger G, Oberhollenzer F, Willeit J, Kiechl S, Wick G: Serum soluble heat shock protein 60 is elevated in subjects with atherosclerosis in a general population. Circulation 2000;102: 14-20.

56 Chen W, Syldath U, Bellmann K, Burkart V, Kolb H: Human $60-\mathrm{kDa}$ heat-shock protein: a danger signal to the innate immune system. J Immunol 1999;162:3212-3219.

57 Hammerer-Lercher A, Mair J, Bonatti J, Watzka SBC, Puschendorf B, Dirnhofer S: Hypoxia induces heat shock protein expression in human coronary artery bypass grafts. Cardiovasc Res 2001;50:115-124.

-58 Kanwar RK, Kanwar JR, Wang D, Ormrod DJ, Krissansen GW: Temporal expression of heat shock proteins 60 and 70 at lesion-prone sites during atherogenesis in ApoE-deficient mice. Arterioscler Thromb Vasc Biol 2001; 21:1991-1997.

-59 Andersson U, Erlandsson-Harris H, Yang H, Tracey KJ: HMGB1 as a DNA-binding cytokine. J Leukoc Biol 2002;72:1084-1091.

60 Andersson U, Wang H, Palmblad K, Aveberger AC, Bloom $\mathrm{O}$, Erlandsson-Harris $\mathrm{H}$, Janson A, Kokkola R, Zhang M, Yang H, Tracey KJ: High mobility group 1 protein (HMG-1) stimulates proinflammatory cytokine synthesis in human monocytes. J Exp Med 2000;192:565-570.

-61 Wang H, Yang H, Czura CJ, Sama AE, Tracey KJ: HMGB1 as a late mediator of lethal systemic inflammation. Am J Respir Crit Care Med 2001;164:1768-1773.

-62 Wang H, Bloom O, Zhang M, Vishnubhakat JM, Ombrellino M, Che J, Frazier A, Yang H, Ivanova S, Borovikova L, Manogue KR, Faist E, Abraham E, Andersson J, Andersson U, Molina PE, Abumrad NN, Sama A, Tracey KJ: HMG-1 as a late mediator of endotoxin lethality in mice. Science 1999;285:248-251.

- 63 Park JS, Svetkauskaite D, He Q, Kim JY, Strassheim D, Ishizaka A, Abraham E: Involvement of Toll-like receptors 2 and 4 in cellular activation by high mobility group box 1 protein. J Biol Chem 2004;279:73707377.
64 Kalinina N, Agrotis A, Antropova Y, DiVitto G, Kanellakis P, Kostolias G, Ilyinskaya O, Tararak E, Bobik A: Increased expression of the DNA-binding cytokine HMGB1 in human atherosclerotic lesions: role of activated macrophages and cytokines. Arterioscler Thromb Vasc Biol 2004;24:2320-2325.

65 Abeyama K, Stern DM, Ito Y, Kawahara K, Yoshimoto Y, Tanaka M, Uchimura T, Ida N, Yamazaki Y, Yamada S, Yamamoto Y, Yamamoto $\mathrm{H}$, Iino S, Taniguchi N, Maruyama I: The N-terminal domain of thrombomodulin sequesters high-mobility group-B1 protein, a novel antiinflammatory mechanism. J Clin Invest 2005;115:1267-1274.

66 Cipollone F, Iezzi A, Fazia M, Zucchelli M, Pini B, Cuccurullo C, De CD, De BG, Muraro R, Bei R, Chiarelli F, Schmidt AM, Cuccurullo F, Mezzetti A: The receptor RAGE as a progression factor amplifying arachidonate-dependent inflammatory and proteolytic response in human atherosclerotic plaques: role of glycemic control. Circulation 2003;108:1070-1077.

67 Hansson GK, Libby P, Schonbeck U, Yan ZQ: Innate and adaptive immunity in the pathogenesis of atherosclerosis. Circ Res 2002;91: 281-291.

68 Tsung A, Sahai R, Tanaka H, Nakao A, Fink MP, Lotze MT, Yang H, Li J, Tracey KJ, Geller DA, Billiar TR: The nuclear factor HMGB1 mediates hepatic injury after murine liver ischemia-reperfusion. J Exp Med 2005;201: 1135-1143.

69 Dybdahl B, Wahba A, Lien E, Flo TH, Waage A, Qureshi N, Sellevold OF, Espevik T, Sundan A: Inflammatory response after open heart surgery: release of heat-shock protein 70 and signaling through toll-like receptor-4. Circulation 2002;105:685-690.

70 Andrassy M, Volz HC, Igwe JC, Funke B, Eichberger SN, Kaya Z, Buss S, Autschbach F, Pleger ST, Lukic IK, Bea F, Hardt SE, Humpert PM, Bianchi ME, Mairbaurl H, Nawroth PP, Remppis A, Katus HA, Bierhaus A: High-mobility group box-1 in ischemiareperfusion injury of the heart. Circulation 2008;117:3216-3226

71 Woo YJ, Taylor MD, Cohen JE, Jayasankar V, Bish LT, Burdick J, Pirolli TJ, Berry MF, Hsu V, Grand T: Ethyl pyruvate preserves cardiac function and attenuates oxidative injury after prolonged myocardial ischemia. J Thorac Cardiovasc Surg 2004;127:1262-1269.

72 Wang P: Andrenomedullin and cardiovascular responses in sepsis. Peptides 2001;22: 1835-1840.

73 Schwarzbauer JE: Alternative splicing of fibronectin: three variants, three functions. Bioessays 1991;13:527-533.

74 Saito S, Yamaji N, Yasunaga K, Saito T, Matsumoto S, Katoh M, Kobayashi S, Masuho Y: The fibronectin extra domain A activates matrix metalloproteinase gene expression by an interleukin-1-dependent mechanism. J Biol Chem 1999;274:30756-30763.
5 Okamura Y, Watari M, Jerud ES, Young DW, Ishizaka ST, Rose J, Chow JC, Strauss JF III: The extra domain A of fibronectin activates Toll-like receptor 4. J Biol Chem 2001;276: 10229-10233.

-76 Tan MH, Sun Z, Opitz SL, Schmidt TE, Peters JH, George EL: Deletion of the alternatively spliced fibronectin EIIIA domain in mice reduces atherosclerosis. Blood 2004; 104:11-18.

77 van Keulen JK, de Kleijn DP, Nijhuis MM, Busser E, Velema E, Fijnheer R, van der GY, Moll FL, de Vries JP, Pasterkamp G: Levels of extra domain A containing fibronectin in human atherosclerotic plaques are associated with a stable plaque phenotype. Atherosclerosis 2007;195:e83-e91.

78 Hessian PA, Edgeworth J, Hogg N: MRP-8 and MRP-14, two abundant $\mathrm{Ca}^{2+}$-binding proteins of neutrophils and monocytes. J Leukoc Biol 1993;53:197-204.

79 Roth J, Vogl T, Sorg C, Sunderkötter C: Phagocyte-specific S100 proteins: a novel group of proinflammatory molecules. Trends Immunol 2003;24:155-158.

80 Frosch M, Strey A, Vogl T, Wulffraat NM, Kuis W, Sunderkotter C, Harms E, Sorg C, Roth J: Myeloid-related proteins 8 and 14 are specifically secreted during interaction of phagocytes and activated endothelium and are useful markers for monitoring disease activity in pauciarticular-onset juvenile rheumatoid arthritis. Arthritis Rheum 2000; 43:628-637.

81 Teigelkamp S, Bhardwaj RS, Roth J, Meinardus-Hager G, Karas M, Sorg C: Calcium-dependent complex assembly of the myeloic differentiation proteins MRP-8 and MRP14. J Biol Chem 1991;266:13462-13467.

82 Vogl T, Ludwig S, Goebeler M, Strey A, Thorey IS, Reichelt R, Foell D, Gerke V, Manitz MP, Nacken W, Werner S, Sorg C, Roth J: MRP8 and MRP14 control microtubule reorganization during transendothelial migration of phagocytes. Blood 2004;104: 4260-4268.

83 Nacken W, Roth J, Sorg C, Kerkhoff C: S100A9/S100A8: Myeloid representatives of the $\mathrm{S} 100$ protein family as prominent players in innate immunity. Microsc Res Tech 2003; 60:569-580.

84 Ahmad A, Bayley DL, He S, Stockley RA: Myeloid related protein-8/14 stimulates interleukin-8 production in airway epithelial cells. Am J Respir Cell Mol Biol 2003;29:523530 .

85 Nacken W, Roth J, Sorg C, Kerkhoff C: S100A9/S100A8: Myeloid representatives of the $\mathrm{S} 100$ protein family as prominent players in innate immunity. Microsc Res Tech 2003; 60:569-580.

86 Croce K, Gao H, Wang Y, Mooroka T, Sakuma M, Shi C, Sukhova GK, Packard RR, Hogg N, Libby P, Simon DI: Myeloid-related protein-8/14 is critical for the biological response to vascular injury. Circulation 2009; 120:427-436. 
87 Ionita MG, Vink A, Dijke IE, Laman JD, Peeters W, van der Kraak PH, Moll FL, de Vries JP, Pasterkamp G, de Kleijn DP: High levels of myeloid-related protein 14 in human atherosclerotic plaques correlate with the characteristics of rupture-prone lesions. Arterioscler Thromb Vasc Biol 2009;29:12201227.

\$8 Edgeworth J, Gorman M, Bennett R, Freemont $\mathrm{P}, \operatorname{Hog} \mathrm{N}$ : Identification of $\mathrm{p} 8,14$ as a highly abundant heterodimeric calcium binding protein complex of myeloid cells. J Biol Chem 1991;266:7706-7713.

-89 McCormick MM, Rahimi F, Bobryshev YV, Gaus K, Zreiqat H, Cai H, Lord RSA, Geczy CL: S100A8 and S100A9 in human arterial wall: implications for atherogenesis. J Biol Chem 2005;280:41521-41529.

-90 Vogl T, Tenbrock K, Ludwig S, Leukert N, Ehrhardt C, van Zoelen MAD, Nacken W, Foell D, van der Poll T, Sorg C, Roth J: MRP8 and MRP14 are endogenous activators of Toll-like receptor 4, promoting lethal, endotoxin-induced shock. Nat Med 2007;13: 1042-1049.

-91 Altwegg LA, Neidhart M, Hersberger M, Muller S, Eberli FR, Corti R, Roffi M, Sutsch G, Gay S, von Eckardstein A, Wischnewsky MB, Luscher TF, Maier W: Myeloid-related protein $8 / 14$ complex is released by monocytes and granulocytes at the site of coronary occlusion: a novel, early, and sensitive marker of acute coronary syndromes. Eur Heart J 2007;28:941-948.

92 Morrow DA, Wang Y, Croce K, Sakuma M, Sabatine MS, Gao H, Pradhan AD, Healy AM, Buros J, McCabe CH, Libby P, Cannon CP, Braunwald E, Simon DI: Myeloid-related protein 8/14 and the risk of cardiovascular death or myocardial infarction after an acute coronary syndrome in the Pravastatin or Atorvastatin Evaluation and Infection Therapy: Thrombolysis in Myocardial Infarction (PROVE IT-TIMI 22) trial. Am Heart J 2008; 155:49-55.
$\$ 93$ Healy AM, Pickard MD, Pradhan AD, Wang Y, Chen Z, Croce K, Sakuma M, Shi C, Zago AC, Garasic J, Damokosh AI, Dowie TL, Poisson L, Lillie J, Libby P, Ridker PM, Simon DI: Platelet expression profiling and clinical validation of myeloid-related protein-14 as a novel determinant of cardiovascular events. Circulation 2006; 113:2278-2284.

94 Berliner JA, Territo MC, Sevanian A, Ramin S, Kim JA, Bamshad B, Esterson M, Fogelman AM: Minimally modified low density lipoprotein stimulates monocyte endothelial interactions. J Clin Invest 1990; 85:1260-1266.

95 Berliner JA, Subbanagounder G, Leitinger N, Watson AD, Vora D: Evidence for a role of phospholipid oxidation products in atherogenesis. Trends Cardiovasc Med 2001; 11:142-147.

96 Liao F, Berliner JA, Mehrabian M, Navab M, Demer LL, Lusis AJ, Fogelman AM: Minimally modified low density lipoprotein is biologically active in vivo in mice. J Clin Invest 1991;87:2253-2257.

97 Miller YI, Viriyakosol S, Binder CJ, Feramisco JR, Kirkland TN, Witztum JL: Minimally modified LDL binds to CD14, induces macrophage spreading via TLR4/MD-2, and inhibits phagocytosis of apoptotic cells. J Biol Chem 2003;278:1561-1568.

98 Miller YI, Viriyakosol S, Worrall DS, Boullier A, Butler S, Witztum JL: Toll-Like receptor 4-dependent and -independent cytokine secretion induced by minimally oxidized low-density lipoprotein in macrophages. Arterioscler Thromb Vasc Biol 2005;25:1213-1219.

-99 Choi SH, Harkewicz R, Lee JH, Boullier A, Almazan F, Li AC, Witztum JL, Bae YS, Miller YI: Lipoprotein accumulation in macrophages via Toll-like receptor-4-dependent fluid phase uptake. Circ Res 2009; 104:1355-1363.

100 Huo Y, Zhao L, Hyman MC, Shashkin P, Harry BL, Burcin T, Forlow SB, Stark MA, Smith DF, Clarke S, Srinivasan S, Hedrick CC, Pratico D, Witztum JL, Nadler JL, Funk CD, Ley K: Critical role of macrophage 12/15-lipoxygenase for atherosclerosis in apolipoprotein E-deficient mice. Circulation 2004;110:2024-2031.
01 Bolick DT, Srinivasan S, Whetzel A, Fuller LC, Hedrick CC: 12/15 Lipoxygenase mediates monocyte adhesion to aortic endothelium in apolipoprotein E-deficient mice through activation of RhoA and NF- $\mathrm{B}$. Arterioscler Thromb Vasc Biol 2006;26: 1260-1266.

102 Shi H, Kokoeva MV, Inouye K, Tzameli I, Yin H, Flier JS: TLR4 links innate immunity and fatty acid-induced insulin resistance. J Clin Invest 2006;116:3015-3025.

103 Liu X, Ukai T, Yumoto H, Davey M, Goswami S, Gibson FC III, Genco CA: Toll-like receptor 2 plays a critical role in the progression of atherosclerosis that is independent of dietary lipids. Atherosclerosis 2008; 196:146-154.

104 Lee JY, Zhao L, Youn HS, Weatherill AR, Tapping R, Feng L, Lee WH, Fitzgerald KA, Hwang DH: Saturated fatty acid activates but polyunsaturated fatty acid inhibits Toll-like receptor 2 dimerized with Tolllike receptor 6 or 1. J Biol Chem 2004;279: 16971-16979.

105 Suganami T, Tanimoto-Koyama K, Nishida J, Itoh M, Yuan X, Mizuarai S, Kotani H, Yamaoka S, Miyake K, Aoe S, Kamei Y, Ogawa Y: Role of the Toll-like receptor 4/ NF- $\kappa B$ pathway in saturated fatty acid-induced inflammatory changes in the interaction between adipocytes and macrophages. Arterioscler Thromb Vasc Biol 2007;27:84-91.

106 Erridge C, Samani NJ: Saturated fatty acids do not directly stimulate Toll-like receptor signaling. Arterioscler Thromb Vasc Biol 2009;29:1944-1949.

107 Schaeffler A, Gross P, Buettner R, Bollheimer C, Buechler C, Neumeier M, Kopp A, Schoelmerich J, Falk W: Fatty acid-induced induction of Toll-like receptor-4/nuclear factor- $\kappa \mathrm{B}$ pathway in adipocytes links nutritional signalling with innate immunity. Immunology 2009;126:233-245. 